\title{
Library change as a branding opportunity \\ Connect, reflect, research, discover
}

$\mathbf{P}$ rominent library changes, such as a building renovation, provide the perfect opportunity to re-examine the library brand. The promotion and publicity associated with big library changes of any kind put the spotlight on the library. This is a good time for library staff to examine the librarys image, identify its strengths, and try to position the library, relative to the competition (other information resources and services) favorably in library users minds. In the case of a building renovation, the branding process can also in uence decision-making regarding new building spaces, library services, and collections.

In December 2004, the Biomedical Library at the University of California-San Diego (UCSD) moved from its permanent location near the medical and pharmacy schools, home of many of the library s primary clientele, to the main library for the duration of a renovation and expansion project, which lasted until August 2006. Journal and book collections, equipment, and staff were all moved to the temporary location.

During the temporary relocation, the staff considered how to identify and promote the value of the library, physical and virtual, old and new. Was the library still relevant to library users? In the age of Google, why would users choose to use the new library (or its Web site) instead of the competition (Google, other libraries, bookstores, etc.)? Why should they decide to visit the physical library instead of just searching online? The library staff considered these issues and identi ed the librarys strengths, which became the core of the library brand.

\section{What is a library brand?}

A library brand has been de ned as all the things that come to mind, all the expectations they have, when they hear the word library, and how you wish people to perceive your library. The former is referred to as brand identity and the latter as brand aspiration. ${ }^{1}$ Having a brand creates a choice in the mind of the user, allowing people to distinguish between your library and the competition, so that hopefully they choose your library. A brand can also be viewed as a promise that an organization makes and strives to keep. ${ }^{2}$ Sometimes the concept of branding is too narrowly construed as merely logo development and matching graphics. The brand applies to all faces of the library, the Web site as well as the physical library. Every library has a brand whether the library staff realize it or not. Proactively identifying and crafting a library brand is important for attracting and retaining users, and assuring that all library services and resources are in alignment with library goals and values.

\section{Getting up to speed}

The rst step in the librarys branding process was to re-examine the library mission statement and core values, written five years before but still largely up to date. The mission statement simply says: To provide a gateway to organized biomedical information in support of research, education, and

Nancy F. Stimson is outreach services librarian in the Biomedical Library at the University of California-San Diego, e-mail: nstimson@ucsd.edu

○) 2007 Nancy F. Stimson 
patient care. The values document informed the library branding process by organizing values pertaining to library and information access, staff, and collections in terms of what our users want and what we want to be seen as.

Inquiries were sent to two marketing discussion groups, ACADLIBPR (academicpr@ala.org) and MRKTLIB (mrktlib@listserv.louisville.edu), to elicit ideas and experiences from other librarians. A literature search revealed numerous articles about library branding. The Special Libraries Association publication, Information Outlook (and its predecessor, Special Libraries), has published many articles on this topic. More speci c articles include Brodsky s article about using a new library building as an opportunity to market the library, ${ }^{3}$ and an article by Simon about marketing libraries using library spaces and features for marketing purposes. ${ }^{4}$ Shill and Tonner discussed the impact of speci $\mathrm{c}$ physical improvements in academic libraries on the use of those facilities. ${ }^{5}$ Franklin and Plum, in their study of academic health sciences libraries, concluded that most of the people surveyed accessed their library remotely instead of in person, and that librarians should accept that and not worry about low in-house use statistics. ${ }^{6}$

Most famously, the OCLC report, Perceptions of Libraries and Information Resources, served as a wake-up call about how many library users from a variety of libraries think about libraries as just being about books! This report is a reminder that the library brand is the perception the user has of the library and is not always under the library s control. Web sites such as MarketingProfs.com and FrugalMarketing.com provided key information about marketing and branding from a general business perspective.

\section{Developing the brand}

To introduce the staff to branding and its importance for the library, a trainer from the campus staff education and develop- ment department was asked to help plan the branding project and to moderate the staff brainstorming sessions. The entire library staff then met to discuss:

Why should anyone physically visit the library anymore?

What makes our library unique?

Why do library users choose our libraries instead of the competition?

What will it be like in the new building?

The branding concept needed to be accepted by the entire staff, since every staff member, as a library ambassador, conveys the brand and makes it true, or not. ${ }^{8}$ However, the process of developing the brand was not easy for some staff members to understand and accept. It is a somewhat amorphous concept, and marketing ideas in general are perceived as alien and even suspect by some library staff. One staff member worried whether the library could live up to what the brand promised. It is notable that the library director originated the idea of developing a library brand, and promoted and pushed the project, top down, among the library staff, which no doubt led to greater staff participation and acceptance.

The information from the brainstorming sessions was condensed into a grid of core brand values that represented the qualities for which the library staff wanted the library to be known. ${ }^{9}$ The items in the grid were then further distilled into the key ideas which made up the brand statement.

The brand statement was reviewed to make sure it applied to not only the physical library, but also the library Web site, library services, and all other aspects of the library. During this process, recent data and feedback from library users (entrance survey results and health sciences graduate student focus group transcripts) were reviewed and considered. The entrance survey results revealed that undergraduate students were the majority of the library visitors, and that the main activity in the library was studying. The focus group participants, health sciences graduate students, indicated, quite 
vociferously, that their main concern was nding a quiet place to study, and that they preferred a place of their own apart from the undergraduate students. The library incorporated this feedback into both the branding process and space and policy planning for the new building.

\section{Creating a tagline}

The brand statement is long, re ecting the complexities of an academic health sciences library with a rich assortment of resources, services, and spaces. In order to communicate the essence of the brand to the public, the library also developed a tagline, which captures the essence of a company or product brand. ${ }^{10} \mathrm{~A}$ branding team was established to propose a tagline for the library. Ideas were solicited from library staff and more than 50 suggestions were received. Six tagline candidates were chosen and a poll was posted on the library Web site to gather input from library users. The library staff also voted on their favorite taglines. The library administration slightly adjusted the winning tagline to create: Connect. Re ect. Research. Discover.

This tagline is effective because it is short, yet each word has multiple meanings to the user. For instance, connect refers to connecting online via the library Web site, connecting with library staff in person or online, and connecting with friends and colleagues within the library. In short, together the library staff and library users developed a versatile and classy tagline, which will hopefully remain relevant for a long time. It should be noted, however, that some library staff members confused the brand and tagline concepts and thought that the tagline was the brand. Explaining the differences more clearly to staff in the future should eliminate this confusion.

\section{Applying the brand}

After the brand has been developed, what should the library do with it? The library staff has looked for ways to highlight and promote the aspects of the brand that seem to resonate with user values.

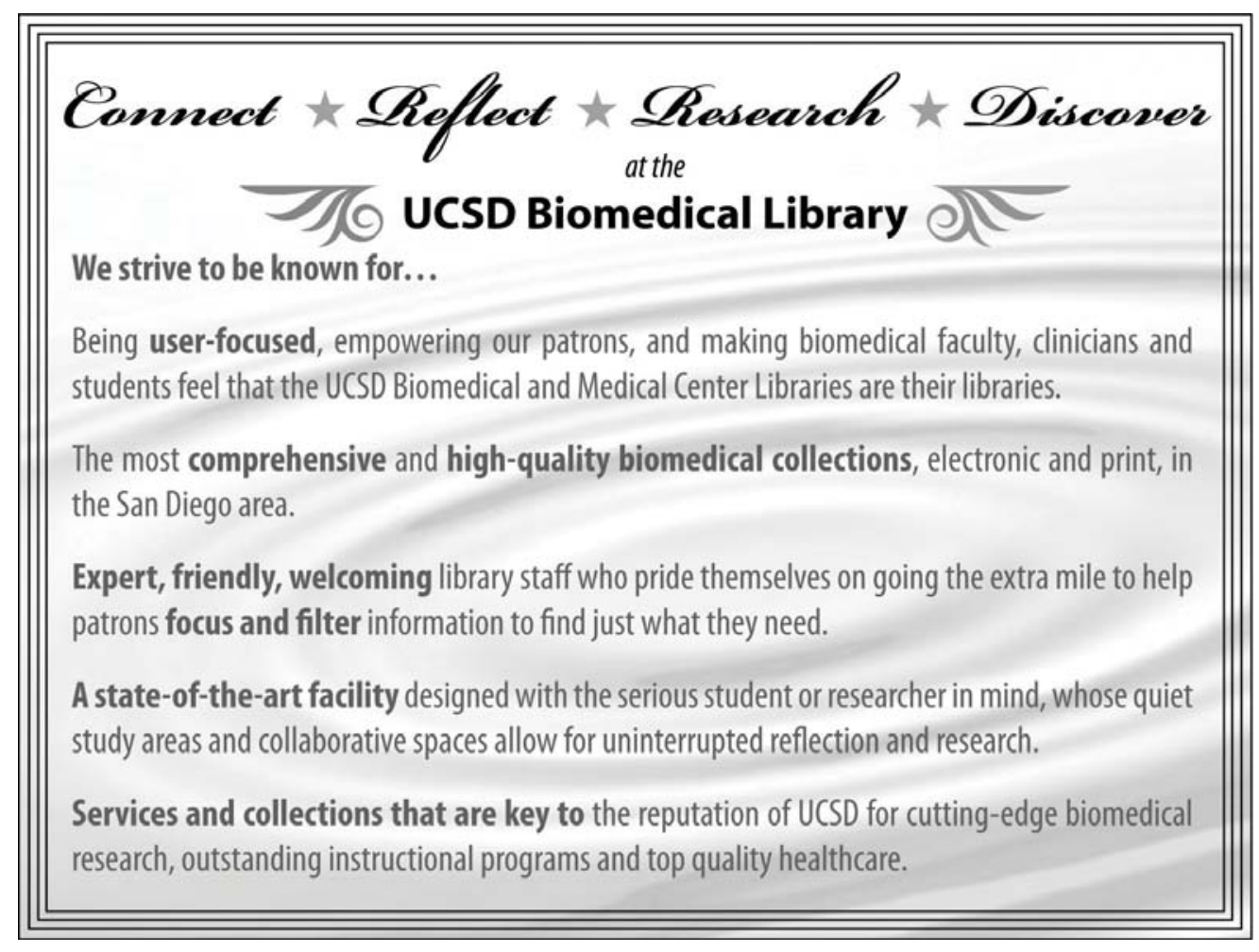

UCSD Biomedical Library Brand Statement 
For instance, since the focus group results indicated that health sciences graduate students wanted a quiet place to study, the library has promoted itself as a place for quiet, serious study and goes to extra lengths to keep the library as quiet as possible, especially during nals. This distinguishes this library from the competition, several of the other libraries on campus that are much noisier. The overlap of the branding project and the library renovation led to building use decisions that might not otherwise have been made.

For instance, a graduate study area for graduate students only was created outside the main library and is open $24 / 7$ via card key access, even when the library itself is closed.

\section{Keeping the brand alive}

In order to keep the brand alive in the minds of library staff, each staff member was given a small, attractive card containing the brand statement. Several staff members have this card prominently posted in their of ces. When the library staff moved into the new building, they were each given a high-quality, ceramic mug with the tagline written on it.

About a year after the brand was developed, a brand checkup was held so that the staff could review the brand and discuss what the library was doing or should do to support it. ${ }^{11}$ Supervisors were encouraged to emphasize the brand in new staff training, and to use it as a benchmark for staff performance evaluations.

Despite some staff skepticism about the branding process, one staff member did say that she thought that the amorphous branding concept had been successfully systematized and translated into a logical series of concrete steps, and another thought the process was intensive and interesting.

In the near future, the brand will be unveiled to library users by posting it on the library Web site, discussing it on the library blog, creating a brochure, etc.

The library brand makes a number of promises to users, and once the brand is shared with the outside world, the library staff must be prepared to deliver what they promise. In the meantime, the library tagline is promoted on the library Web site, newsletter, postcards, giveaways, and in other places. Several staff members also include the tagline in their e-mail signature blocks.

The library outreach services coordinator was appointed the informal keeper of the brand and, as such, tries to think of additional ways to promote the brand among the library users and staff, to keep the brand alive.

\section{Conclusion}

The brand development process was long and complex, but it was well worth the time and effort required. The process made the library staff take an honest look at the library, and identify and articulate its strengths. The library brand will continue to serve as a benchmark for strategic planning, space and services initiatives, and marketing programs.

Working on the brand during the building renovation worked well, since information gained in one project informed and improved decisions made in the other. Although the renovation project was an impetus to develop the library brand, the branding process itself, the brainstorming and re ection, was professionally invigorating for all levels of library staff.

While designing and carrying out this project without the assistance of consultants may have lengthened the project, it also allowed the library staff to take ownership of the brand, and saved the library a lot of money. Branding is an evolving process, always a work in progress.

The UCSD Biomedical Library will continue to look for opportunities to implement the brand in ways that are meaningful for both library users and library staff.

\section{Acknowledgements}

The author thanks Susan Starr and Alice Witkowski for their encouragement and assistance. 


\section{Notes}

1. Beth Dempsey, Target your brand: Build an identity that works in the age of the superstore, Library Journal 129(13): 3235.

2. University of Maryland University College. 2005. Identity Standards Guide. Interim: November 2005-March 2007. p. 2.

3. Karen Brodsky, If you build it will they come? Using a new library building to establish a culture of marketing, The Reference Librarian 82: 183197.

4. Matthew Simon, Marketing libraries through their physical environment, Wilson Library Bulletin 66(7): 33-35, 120.

5. Harold B. Shill and Shawn Tonner. 2004. Does the building still matter? Usage patterns in new, expanded, and renovated libaries, 1995-2002, College \& Research Libraries 65(2): 123-150.

6. Brinley Franklin and Terry Plum, Library usage patterns in the electronic information environment, Information Research 9(4), informationr.net/ir/9-4 /paper187.html.

7. OCLC Online Computer Library Center, Inc. 2005, Perceptions of Libraries and Information Resources, Dublin, OH: OCLC Online Computer Library Center, Inc., www.oclc.org/reports/2005 perceptions. htm.

8. Lissa Krull, Lissa Living your library s brand, Indiana Libraries 20(2):16-20.

9. Mike Moser, United We Brand: How to Create a Cohesive Brand That's Seen, Heard and Remembered (Boston: Harvard Business School Press): 11.

10. Chris Olson, Slogans and taglines. There is a difference! Marketing Treasures 14(6).

11. Mark Shipley, Keeping the brand healthy: The annual brand checkup, www. marketingprofs.com/7/keeping-brandshealthy-annual-checkup-shipley.asp (registration required). $n$

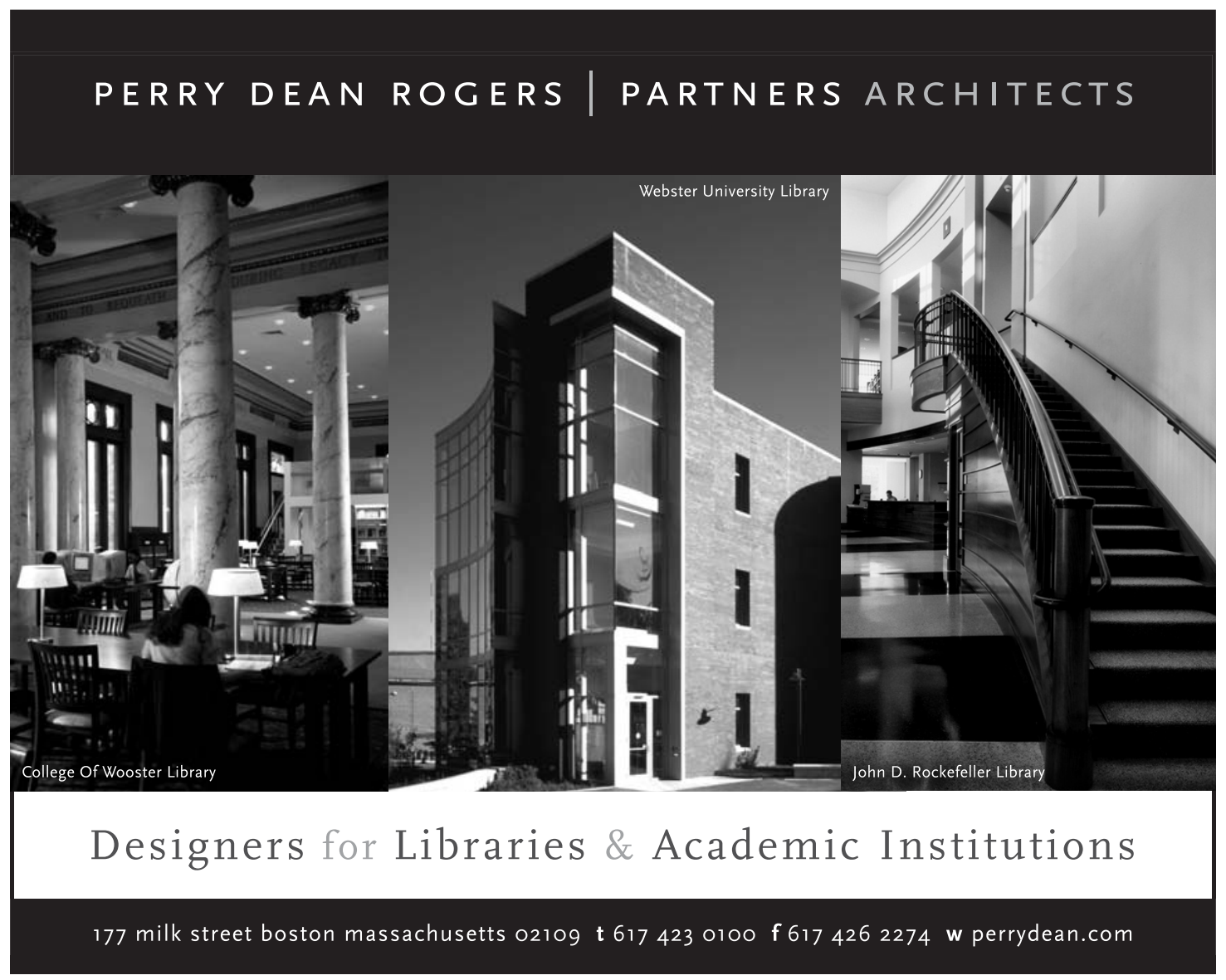

